\title{
Dampak Pengembangan Sarana Pariwisata Terhadap Peningkatan Jumlah Pengunjung Di Wisata Alam Air Panas Angseri, Tabanan
}

I Gusti Ayu Widyarini a, 1, I Nyoman Sunartaa, 2

${ }_{1}^{1}$ Tuwik.widyarini@gmail.com, 2 nyoman_sunarta@unud.ac.id

a Program Studi S1 Destinasi Pariwisata, Fakultas Pariwisata,Universitas Udayana, Jl. Dr. R. Goris, Denpasar, Bali 80232 Indonesia

\section{Abstract}

Tourism facilities is one of the most influential in increasing the number of visits. If a tourist place has a good tourism facilities then the interest of visitors to travel will increase.

Angseri nature hot water is located in Tabanan District, while in the field of existing tourism facilities are considered good enough, although there are still some facilities that have not received attention from the manager such as waiting queue and park for children. This type of research is qualilative and quantitative research, the research method used in this research method of interview, observation, and documentation, the techniques of determining informants used are snowball procedures, and data analysis using qualitative descriptive analysis.

The results obtained in this study is that tourism facilities available in the field can be good enough, although there are still some facilities that have not met the standards, when the development of tourism facilities conducted by the Angseri hot water tourism management proved to have a good influence on the increasing number of visitors who each month increased

\section{Keywords: Development Impact, Tourism Facility, Number of Visitors}

\section{PENDAHULUAN}

Sektor pariwisata saat ini merupakan salah satu sektor penyumbang devisa terbesar di Indonesia. Dewasa ini pariwisata berkembang kearah yang lebih baik. Hal demikian tidak terlepas dari jasa layanan yang diberikan oleh penyedia jasa yang terdapat di Indonesia, pelayanan yang dimaksud seperti sarana yang di sediakan sehingga mempengaruhi pengalaman wisatawan ketika datang berkunjung. Selain ketersediaan sarana pariwisata melakukan pembaharuan atau pengembangan terhadap sarana pariwisata itu juga penting dilakukan. Pengembangan sarana pariwisata khususnya di daya tarik wisata akan memberikan dampak positif bagi daya tarik itu sendiri.

Air Panas Angseri terletak di Desa Angseri, tepatnya berada di bawah kaki Gunung Batukaru Kabupaten Tabanan. Pada tahun 2007 masyarakat setempat memiliki inisiatif untuk mengembangkan pemandian air panas ini menjadi kawasan pemandian umum. Adapun fasilitas yang disediakan yaitu kolam pemandian yang besar kiranya mampu menampung 20 hingga 30 orang dan terdapat ruangan pemandian khusus sebanyak sembilan ruangan, selanjutnya terdapat sarana lainnya yaitu lahan parkir, loket tiket, warung makan atau restoran, toilet serta tempat mengganti pakaian. Namun ketika dilapangan terdapat beberapa fasilitas yang tidak tersedia seperti tempat pengganti pakaian yang kurang bersih serta minim pencahyaan, kurangnya tempat membilas, fasilitas loker dan fasilitas tempat menunggu antrian. Apabila fasilitas ini tidak ditingkatkan dan dikembangkan menjadi lebih baik maka wisata alam Air Panas Angseri menjadi tertinggal dengan daya tarik serupa yang ada di Kabupaten Tabanan bahkan di Bali . Dengan ketatnya persaingan antar daya tarik serupa, maka pihak pengelola harus lebih jeli dalam melihat kekurangan yang dimiliki dan memperbaiki sarana yang ada. Perkembangan sarana pariwisata ini juga bermanfaat untuk menarik kembali minat wisatawan yang sudah pernah datang untuk datang kembali dan menarik minat wisatawan untuk datang lebih banyak lagi. Dengan semakin ketatnya daya saing maka peneliti melakukan penelitian untuk menemukan dampak pengembangan sarana pariwisata terhadap peningkatan jumlah pengunjung di Wisata Alam Air Panas Angseri. Tujuan penelitian ini yaitu untuk mengetahui pengembangan sarana pariwisata di Wisata Alam Air Panas Angseri dan untuk mengetahui dampak pengembangan sarana pariwisata terhadap peningkatan kunjungan di Wisata Alam Air Panas Angseri

\section{KEPUSTAKAAN}

\subsection{Telaah Hasil Penelitian Sebelumnya}

Adapun telaah hasil penelitian oleh Ugy Soebiyantoro(2009). berjudul "Pengaruh 
Ketersediaan Sarana Prasarana, Sarana Transportasi Terhadap Kepuasan Wisatawan". Tujuan dari penelitian ini untuk mengetahui bagaimana pengaruh ketersediaan sarana prasarana, sarana transportasi terhadap kepuasan wisatawan. Persamaan antara penelitian ini yaitu ingin mengetahui dampak/pengaruh ketersediaan sarana pariwisata di daya tarik wisata. Namun terdapat perbedaan lokasi penelitian. Penelitian ini dilakukan di 20 daya tarik di Kabupaten Kebumen sedangkan penelitian yang akan dilakukan mengambil lokasi di wisata alam Air Panas Angseri, Tabanan.

Selanjutnya penelitian yang dilakukan oleh Suchaina (2014). Penelitian tersebut berjudul "Pengaruh Kualitas Fasilitas Sarana dan Prasarana Terhadap Peningkatan Jumlah Pengunjung Wisata Danau Danu Grati". Metode yang digunakan yaitu metode kualitatif serta menggunakan pendekatan studi kasus. Persamaan antara penelitian yaitu ingin megetahui pengaruh ketersediaan sarana terhadap peningkatan jumlah kunjungan. Namun antara penelitian yang akan dilakukan terdapat perbedaan lokasi penelitian. Penelitian ini mengambil lokasi di daya tarik wisata Danau Danu Grati sedangkan penelitian yang akan dilakukan mengambil loaksi di wisata alam Air Panas Angseri.

\subsection{Deskripsi Konsep}

\subsubsection{Konsep Pengembangan}

Menurut Paturusi

pengembangan yaitu suatu cara dan strategi yang digunakan agar suatu objek dan daya tarik wisata menjadi lebih baik sehingga dapat dikunjungi oleh wisatawan dan mampu memberikan nilai ekonomi bagi masyarakat maupun pemerintah .

$$
\text { Menurut Sunarta (2014). }
$$

Pengembangan potensi yaitu salah satu strategi yang digunakan untuk memperbaiki objek atau daya tarik wisata sesuai dengan kelebihannya sehingga dapat berkembang dengan tujuan yang diinginkan.

\subsubsection{Konsep Pengunjung}

Menurut International Union of official Travel Organization (IUOTO) pengunjung adalah orang atau sekelompok orang yang mendatangi suatu kawasan wisata dengan maksud berwisata dan tidak menerima upah atau melakukan pekerjaan.

Pengunjung digolongkan dalam dua kategori yaitu:

1. Wisatawan (tourist)

Pengunjung yang berkunjung dengan kurun waktu paling sedikit 24 jam di tempat yang dikunjunginya dan tujuannya dapat digolongkan ke dalam klasifikasi sebagai berikut:

a. Pesiar (leisure)

Dengan tujuan relaksasi, liburan, kesehatan, studi, keagamaan, dan olahraga.

b. Hubungan dagang (business), keluarga, pertemuan, misi, dan lain sebagainya.

2. Pelancong (excursionist)

Pengunjung sementara yang datang ke suatu tempat wisata dengan kurun waktu tidak lebih dari 24 jam.

\subsubsection{Sarana Pariwisata}

Suwantoro (2004) Sarana pariwisataan (tourism infrastructure) adalah segala fasilitas yang keberadaanya dapat menghidupkan prasarana kepariwisataan sehingga wisatawan merasa kebutuhanya dapat terpenuhi. Sarana wisata yaitu fasilitas pelengkap yang ada di daerah tujuan wisata yang keberadaanya diperlukan oleh wisatawan sehingga wisatawan dapat menikmati kegiatan wisatanya.

\subsubsection{Konsep Wisata Alam}

Wisata alam merupakan jenis kegiatan wisata yang memanfaatkan alam, sehingga kegiatan wisata ini dapat memberikan kesegaran jasmani dan rohani bagi pengunjung selain itu pengunjung akan memperoleh ilmu, pengalaman, dan rasa peduli terhadap alam (Anonymous, 1982 dalam saragih, 1993).

\section{METODE PENELITIAN}

\subsection{Jenis dan Sumber Data}

Jenis Penelitian ini yaitu penelitian kualitatif dan kuantitatif. Menurut Moleong (2013), penelitian kualitatif adalah penelitian yang bertujuan untuk mengetahui fenomena mengenai hal-hal yang dialami oleh subjek penelitian seperti pola pikir, tindakan, motivasi dan lain sebagainya secara mendalam dan dengan bentuk kata-kata serta bahasa. Data 
kualitatif dalam penelitian ini yaitu peneliti akan menggali informasi mengenai deskripsi mengenai profil Desa Angseri, hasil observasi peneliti selama di lapangan serta wawancara secara mendalam dengan pihak pengelola di daya tarik Wisata Air Panas Angseri. Sedangkan untuk Data kuantitatif, sebagaimana dikemukana oleh Sugiyono (2009:14) merupakan metode yang akan menghasilkan data berupa data statistik yang dapat dinilai dengan angka-angka serta hitungan statistik. Dalam penelitian ini data kuantitatif yaitu data yang berupa jumlah kunjungan wisatawan di Wisata Alam Air Panas Angseri.

Sumber data:

a) Data Primer

Menurut Umar (2009), data primer adalah data yang didapatkan secara langsung oleh peneliti dilapangan. Dalam penelitian ini yang menunjukkan data primer yaitu observasi kondisi di Air Panas Angseri, wawancara mendalam dengan pihak pengelola, pihak pengelola yang dimaksud adalah pengelola daya tarik wisata Air Panas Angseri, Bendesa Adat Desa Angseri, Warga yang tinggal disekitar daya tarik wisata, serta pengunjung daya tarik wisata. Dokumentasi berupa foto-foto penelitian di Air Panas Angseri.

b) Data Sekunder

Menurut Sugiyono (2005 : 62), data sekunder adalah data yang didapatkan oleh peneliti secara tidak langsung, dalam penelitian ini data sekunder berupa data yang diperoleh yang bersumber dari instansi yaitu jumlah kunjungan wisatawan yang diperoleh dari pengelola Wisata Alam Air Panas Angseri, serta jurnal atau literatur yang terkait dengan dampak pengembangan sarana terhadap kunjungan wisatawan ke suatu daya tarik wisata.

\subsection{Teknik Penentuan Informan}

Dalam menentukan informan teknik yang digunakan yaitu Snowball. Dalam prosedur ini, peneliti akan memperoleh data dari informan awal hingga memperoleh data yang cukup dari informan-informan selanjutnya tergantung dengan informan siapa yang pertama kali ditemui. Prosedur ini sering digunakan untuk mencari " informan tersembunyi" (Bungin,2007) . Dalam penelitian ini informan yang sesuai dengan permasalahan yaitu staff/ karyawan Wisata Alam Air Panas Angseri, Ketua/Wakil Pengelola Wisata Alam Air Panas Angseri, Bendesa Adat Desa Angseri.

\subsection{Teknik Pengumpulan Data}

Berikut merupakan tahapan yang digunakan oleh peneliti yaitu melakukan wawancara dengan informan kunci dari kalangan obyek yang diteliti atau dengan pengelola Wisata Alam Air Panas Angseri, observasi dalam penelitian ini dilakukan di Air Panas Angseri dengan tujuan mendapatkan keadaaan, kondisi serta situasi mengenai objek yang sedang diteliti menggunakan penginderaan. Dokumentasi Dalam penelitian ini yang termasuk dalam dokumentasi adalah data jumlah kunjungan wisatawan ke Air Panas Angseri yang diperoleh oleh peneliti melalui pihak pengelola serta foto- foto mengenai kondisi dilapangan yang diambil oleh peneliti langsung.

\subsection{Teknik Analisis Data}

Teknik analisis data yang dilakukan pada penelitian berikut berupa analisis deskriptif kualitatif. Dimana teknik ini akan menggambarkan data yang berbentuk kata atau kalimat yang didapat dan kemudian cara penyusunannya dilakukan dengan tersistem, akurat, dan terpercaya mengenai fakta-fakta yang ada (Moleong dalam Sukmana, 2016).

Setelah itu peneliti akan membuat hasil kesimpulan dari masalah-masalah yang telah ditentukan yang akan dibahas dalam Penelitian ini. Dan selanjutnya peneliti akan memberikan saran untuk peneliti lain berikutnya untuk menyempurnakan kajian mengenai dampak pengembangan sarana pariwisata terhadap peningkatan jumlah pengunjung di wisata alam Air Panas Angseri.

\section{IV.HASIL DAN PEMBAHASAN}

\subsection{Pengembangan Sarana Pariwisata di Wisata Alam Air Panas Angseri}

Pengembangan sarana pariwisata di suatu daya tarik wisata merupakan suatu hal yang penting bagi memajukan serta menjadikan tempat wisata tersebut menjadi lebih baik, selain itu mengembangkan sarana pariwisata di suatu daya tarik juga dapat menunjang dalam peningkatan jumlah kunjungan yang dimana hal tersebut menjadi salah satu alasan mengapa pengembangan dilakukan. Menurut Sunarta 
(2014). Pengembangan potensi yaitu salah satu strategi yang digunakan untuk memperbaiki objek atau daya tarik wisata sesuai dengan kelebihannya sehingga dapat berkembang dengan tujuan yang dinginkan.

Dalam pengembangan sarana pariwisata, pihak pengelola Wisata Alam Air Panas Angseri ini menyatakan bahwa sarana yang tersedia di lokasi Wisata Alam Air Panas Angseri sudah cukup baik dan dapat menunjang keberlangsungan kegiatan pariwisata, namun tidak dapat dipungkiri juga bahwa terdapat beberapa sarana yang masih perlu diadakannya perbaikan dan perlu dilakukan pembenahan mengenai kelengkapan sarana agar dapat memuaskan pengunjung yang datang.

Pengembangan sarana pariwisata di wisata alam Air Panas Angseri dilakukan pada bulan Desember 2016 adapun beberapa sarana yang dikembangkan yakni penambahan toilet, penambahan ruang pengganti, penambahan ruangan membilas dan perbaikan lahan parkir, dan penambahan restoran/ warung. Namun untuk penambahan ruang menunggu/ Gazebo dan taman bermain anak-anak seperti ayunan belum mendapatkan perhatian oleh pihak pengelola. Pengembangan fasilitas yang dimaksud ialah pembenahan, pembaharuan serta perawatan. Berikut merupakan fasilitas dan sarana di wisata alam Air Panas Angseri.

\section{Fasilitas pariwisata di Wisata Alam Air Panas Angseri \\ a. Kolam Pemandian}

Kolam pemandian merupakan fasilitas utama yang ditawarkan oleh wisata alam ini, adapun dua kolam utama yang disuguhkan kepada pengunjung yakni satu kolam berukuran besar diperuntukan kepada orang dewasa serta satu kolam kecil untuk anak-anak. Menurut informasi yang diperoleh selama berada dilapangan pengelola menyebutkan bahwa, akan ada pertambahan kolam dimana kolam ini akan dikhususkan untuk pengunjung asing, penambahan kolam ini memiliki tujuan agar pengunjung asing dapat menikmati pemandangan disekitar lokasi wisata.

\section{b. Private Room}

Private Room merupakan ruangan yang di peruntukan kepada pengunjung apabila pengunjung menginginkan suasana yang santai.
Private room ini cukup diisi sebanyak empat sampai lima orang didalamnya.

Dalam pengembangannya ruangan ini dahulu berbahan dinding bambu dan juga kayu, kemudian pihak pengelola melakukan perbaikan yaitu mengganti bahan bangunan yang awalnya tidak permanen ini menggunakan baja dan dinding menggunakan beton, hal ini dilakukan mengingat kayu dan bambu yang digunakan tidak mampu bertahan lama dan cepat rusak akibat dari terkena uap air panas yang mengandung zat belerang.

\section{c. Air terjun}

Air terjun ialah salah satu atraksi yang dimiliki oleh Air Panas Angseri, dengan letaknya yang strategis yakni berada tepat didepan kolam utama yang dapat dinikmati oleh pengunjung. Selain itu air terjun ini mengeluarakan air yang berwarna jingga dengan suhu air hangat hal ini dikarenakan air yang mengalir mengandung zar belerang.

\section{Sarana yang Tersedia di Wisata Alam Air Panas Angseri}

\section{a. Parkir}

Lahan parkir yang tersedia terdapat dua lokasi yaitu parkir untuk kendaraan roda dua dan kendaraan roda empat. Untuk lahan parkir ini dulunya tidak layak disebabkan lahan yang masih beralaskan tanah.

\section{b. Restoran/ Warung}

Restoran atau warung makan merupakan sarana penunjang dalam keberlangsungan kegiatan pariwisata, di Air Panas Angseri sendiri terdapat satu buah restoran dan satu buah warung sederhana yang dikelola oleh pihak pengelola tidak hanya itu terdapat pula warung lainnya yang dimiliki oleh masyarakat lokal.

\section{c. Toilet, dan Loker}

Sarana ini menjadi sangat penting mengingat atraksi utama di wisata ini ialah berhubungan dengan air dan pemandian. Sebelum dikembangkan sarana toilet tempat mengganti pakaian dan loker belum sepenuhnya dapat memenuhi kebutuhan pengunjung. Namun setelah pengembangan untuk sarana demikian sudah mencukupi dan mampu memenuhi kebutuhan pengunjung. 
3. Jumlah Fasilitas dan Sarana Pariwisata Sebelum dan Sesudah Pengembangan di Wisata Alam Air Panas Angseri.

Sarana pariwisata merupakan segala kelengkapan yang ada di daerah tujuan wisata yang dibutuhkan oleh wisatawan atau pengunjung dalam menikmati perjalanan wisatanya menurut Gamal Suwantoro (1997) dalam Suchaina (2014). Pihak pengelola wisata alam Air Panas Angseri selanjutnya melakukan pengembangan serta perbaikan fasilitas dan sarana pariwisata agar kiranya dapat mendukung kegiatan pengunjung dalam melakukan perjalanan wisatanya.

Berikut merupakan data table jumlah fasilitas dan sarana yang dapat disampaikan:

Table 1. Jumlah fasilitas dan sarana di wisata alam Air Panas Angseri

\begin{tabular}{|l|l|l|l|}
\hline No & Fasilitas dan Sarana & Sebelum & Sesudah \\
\hline 1 & Kolam pemandian & 2 & 2 \\
\hline 2 & Private Room & 6 & 9 \\
\hline 3 & Restoran/Warung & 3 & 4 \\
\hline 4 & $\begin{array}{l}\text { Tempat Mengganti } \\
\text { Pakaian }\end{array}$ & 3 & 4 \\
\hline 5 & Toilet & 2 & 4 \\
\hline 6 & Tempat Membilas & 1 & 3 \\
\hline 7 & Parkir & 2 & 2 \\
\hline
\end{tabular}

Sumber: Pengelola wisata alam Air Panas Angseri (13/05/2017)

Dari table diatas dapat dijelaskan mengenai fasilias dan sarana pariwisata di wisata alam Air. Terlihat bahwa pengembangan yang dilakukan yakni pada room private yang mulanya berjumlah enam kini menjadi sembilan buah ruangan, restoran yang mulanya berjumlah tiga kini menjadi empat, tempat mengganti pakaian yang mulanya berjumlah tiga kini menjadi empat, toilet yang mulanya berjumlah dua kini menjadi empat yakni dua untuk toilet pria dan dua untuk toilet wanita, tempat membilas yang mulanya berjumlah satu saja kini menjadi tiga buah. Dan untuk fasilitas kolam pemandian sampai saat masih berjumlah dua.

\subsubsection{Jumlah Kunjungan Sebelum di Kembangkannya Sarana Pariwisata Di Wisata Alam Air Panas Angseri}

Menurut Pengelola jumlah kunjungan tiap harinya dapat dikatakan tidak begitu ramai, kecuali dihari-hari libur seperti hari Sabtu dan Minggu. Terdapat beberapa faktor penyebabnya yakni, akses jalan menuju wisata alam Air Panas Angseri belum memadai atau masih sulit untuk diakses. Belum lengkapnya sarana penunjang kegiatan pariwisata seperti parkir, toilet, tempat mengganti pakaian dan tempat untuk menaruh pakaian bagi pengunjung (loker). Kurangnya promosi yang dilakukan oleh pihak pengelola.

Pengembangan fasilitas dan sarana pariwisata sendiri diperbaiki pada pertengahan tahun 2016 oleh pihak pengelola.

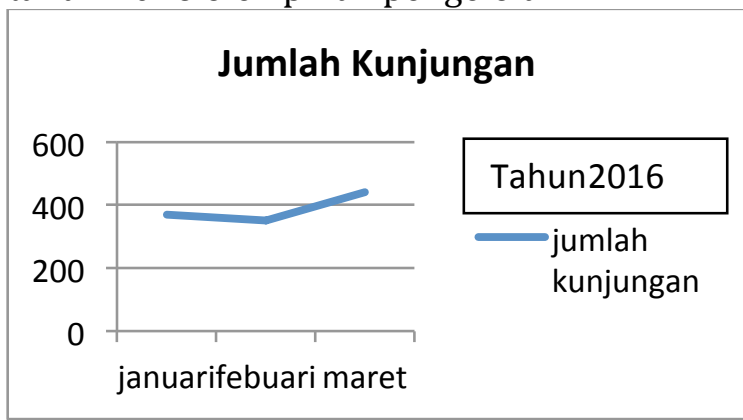

Gambar $4.1 \quad$ Jumlah Kunjungan Sebelum Pengembangan Sarana di Wisata Alam Air Panas Angseri

Sumber:Pengelola wisata alam air panas angseri(13/05/2017)

Dari gambar diatas dapat dijelaskan bahwa pada bulan Januari jumlah kunjungan mencapai 370 orang, pada bulan Februari sebanyak 350 orang kemudian pada bulan maret sebanyak 440 orang. Data ini diperoleh melalui pendapatan dari penjualan tiket pada bulan Januari yakni sebesar Rp 5.250.000, pada bulan Februari sebesar Rp3.500.000, dan pada bulan Maret sebesar Rp 4.500.000, yang dimana masing-masing hasil pendapatan penjualan tiket tiap bulan dibagi harga tiket sebesar $\mathrm{Rp}$. 10.000 /tiket maka diperoleh hasil jumlah kunjungan seperti demikian.

\subsubsection{Jumlah Kunjungan Sesudah Di Kembangkannya Sarana Pariwisata di Wisata Alam Air Panas Angseri}

Sarana pariwisata yang telah dikembangkan oleh pihak pengelola membawa pengaruh baik bagi jumlah kunjungan di wisata alam air panas angseri ini. Hal ini dapat terjadi 
karena sarana yang tersedia sudah mampu memenuhi kebutuhan yang dibutuhkan oleh pengunjung, sarana yang berpenagruh besar adalah jalan menuju wisata ini, dengan perbaikan jalan yang telah dilakukan maka pengunjung tidak kesulitan lagi untuk mencapai ke tempat wisata ini.

Pengembangan fasilitas dan sarana pariwisata sendiri dikembangkan pada bulan Desember 2016 oleh pihak pengelola, berikut merupakan tabel kunjungan wisatawan tiga bulan setelah dilakukannya pengembangan yakni bulan Januari, Februari dan Maret 2017:

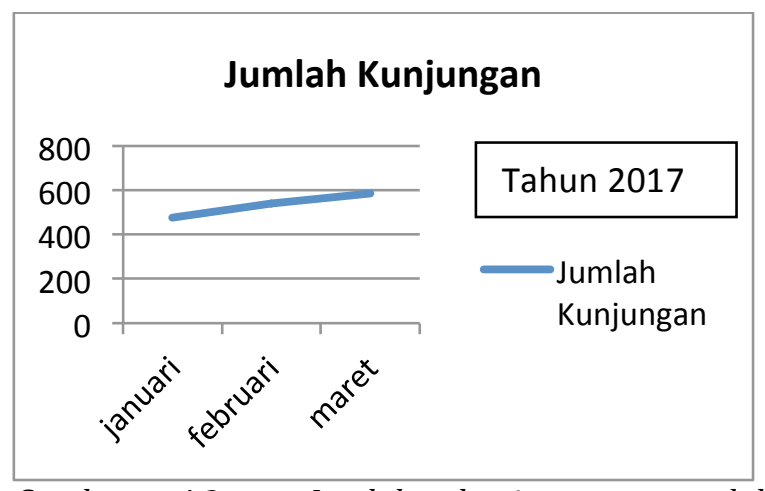

Gambar $4.2 \quad$ Jumlah kunjungan sesudah Pengembangan sarana di Wisata Alam Air Panas Angseri

Sumber:Pengelola wisata alam air panas angseri(13/05/2017)

Dari gambar diatas dapat dijelaskan bahwa pada bulan Januari jumlah kunjungan mencapai 475 orang, pada bulan Februari sebanyak 540 orang kemudian pada bulan Maret sebanyak 585 orang. Data ini diperoleh melalui pendapatan dari penjualan tiket pada Bulan Januari yakni sebesar Rp 5.750.000, pada bulan Februari sebesar Rp5.400.000, dan pada bulan Maret sebesar Rp 5.850.000, yang dimana masing-masing hasil pendapatan penjualan tiket tiap bulan dibagi harga tiket sebesar $\mathrm{Rp}$ 10.000/Tiket maka diperoleh hasil jumlah kunjungan seperti demikian.

\subsection{Dampak Pengembangan Sarana terhadap Jumlah Pengunjung di Wisata Alam Air Panas Angseri}

Pengembangan sarana pariwisata merupakan salah satu modal penting dalam menarik minat pengunjung untuk mendatangi suatu daya tarik wisata. Apabila sarana yang disediakan sudah cukup baik dan mampu memenuhi kebutuhan pengunjung maka pengunjung akan tertarik untuk melakukan perjalanan wisata ke tempat tersebut. Hasil temuan peneliti pada saat melakukan observasi memperoleh pernyataan dari pihak pengelola yaitu Wakil Ketua Pengelola yakni Made Biasa menyatakan bahwa beberapa bulan saat pengembangan sarana yang dilakukan tersebut terjadi peningkatan jumlah pengunjung yang datang dan begitu pula dengan bulan-bulan berikutnya. Pada umumnya pengunjung yang datang ke wisata alam ini untuk berelaksasi dan bersantai sambil berendam. namun tidak sedikit pula pengunjung yang datang justru untuk pengobatan atau sering disebut dengan mandi sehat, walaupun tidak sedikit pula terdapat pengunjung mancanegara yang datang pada saat long holiday.

Jika dilihat dari jumlah kunjungan wisatawan sebelum bulan dikembangkannya jumlah kunjungan di Air Panas Angeri sebesar 1.315 orang per tiga bulan yaitu pada bulan Januari , Februari dan Maret Akan tetapi sejak dikembangkannya sarana pariwisata, mulai bulan Januari, Februari dan Maret tahun 2017 terjadi peningkatan jumlah kunjungan yaitu Januari 475, Februari sebesar 540, Maret sebesar 585. Jadi setelah dikembangkannya sarana pariwisata jumlah pengunjung dalam tiga bulan sebesar 1.600 orang.

Berdasarkan data diatas maka jumlah kunjungan sesudah sebesar 1.600 dikurangi dengan jumlah sebelum sebesar 1.335 maka diperoleh hasil sebesar 265 orang. Dampak dari pengembangan saran pariwisata terhadap jumlah kunjungan meningkat menjadi 285 orang. Dari jumlah ini maka dapat dikatakan bahwa dari pengembangan sarana pariwisata di wisata Alam Air Panas Angseri membawa dampak yang baik dalam hal peningkatan jumlah kunjungan.

\section{PENUTUP}

\subsection{SIMPULAN}

Berdasarkan hasil penelitian, kesimpulan yang dapat ditarik oleh peneliti yakni:

1. Wisata Alam Air Panas Angseri sendiri memiliki fasilitas dan sarana yang sudah cukup baik berkat pengembangan yang telah dilakukan oleh pihak pengelola, pengembangan sarana pariwisata dilakukan pada bulan Desember 2016 pengembangan tersebut berupa penambahan sejumlah sarana seperti room private, tempat 
mengganti pakaian, toilet, tempat membilas, restoran, serta perbaikan pada lahan parkir kendaraan roda dua.

2. Tingkat pengunjung di Wisata Alam Air Panas Angseri setiap bulannya mengalami peningkatan, Hal ini terbukti dari jumlah pendapatan dari penjualan tiket masuk untuk wisata alam ini yang terus meningkat.

\subsection{SARAN}

Saran yang dapat peneliti sampaikan sebagai berikut:

1. Dalam mempromosikan, pihak pengeloa sudah cukup baik namun promosi harus lebih ditingkatkan lagi dengan bekerjasama dengan travel agen agar Wisata Air Panas Angseri lebih dikenal lagi oleh wisatawan mancaegara.

2. Untuk fasilitas menunggu kiranya harus dibangun dan diperbaharui, seperti fasilitas gazebo yang kana dimanfaatkan oleh pengunjung ketikamenunggu antrian atau hanya untuk duduk bersantai.

\section{DAFTAR PUSTAKA}

Badrudin, Rudi. 2001. "Tourism Management". Jakarta : Gramedia Pustaka Utama

Bungin,2007. Penelitian Kualitatif. Jakarta: Prenada Media Group.

Fandeli, C. (2002). Perencanaan Kepariwisataan Alam. Fakultas Kehutanan Universitas Gadjah Mada, Bulaksumur, Yogyakarta.

Moleong, Lexy J. 2013. Metode Penelitian Kualitatif. Edisi Revisi, Bandung: PT. Remaja.

Paturusi, Samsul A. 2001, Perencanaan Tata Ruang Kawasan Pariwisata, Program Pasca Sarjana Universitas Udayana Denpasar, Bali.

Republik Indonesia. 2009. Undang-Undang RI No. 10 Tahun 2009 tentang Kepariwistaan. Lembaran Negara RI Tahun 2009, No 11. Jakarta Sekretariat Negara.

Soebiyantoro, Ugy. 2009. Pengaruh Ketersediaan Sarana Prasarana, Sarana Transportasi Terhadap Kepuasan Wisatawan, Surabaya.

Suchina. Pengaruh Kualitas Fasilitas Sarana dan Prasarana Terhadap Peningkatan Jumlah Pengunjung Wisata Danau Ranu Gati. 2014.

Sugiyono. (2005). Metode Penelitian Administrasi. Bandung: Alfabeta.

Sugiyono. (2009). Metode Penelitian Kuantitatif, Kualitatif dan $R \& D$, Bandung: Alfabeta.

Sunarta, I Nyoman dan I Gede Anom Sastrawan (2014). Strategi Pengembangan Potensi Wisata Bahari di Pantai Crystal Bay Desa Sakti, Kec.Nusa Penida, Kab. Klungkung, Vol.2 No.2, 2014.
Suwantoro, Gamal. 2014. Dasar-dasar Pariwisata. Yogyakarta: ANDI.

Suwantoro, Gamal. 2004. Dasar-Dasar Pariwisata. Yogya karta: ANDI

Usman, Husein dan Purnoo Setiadi Akbar. 2009. Metode Penelitian Sosial. Jakarta

Sumber lain: monografi desa angseri tabanan - Google Searchhttps://www.google.com/search?q=monografi+des $a+$ angseri+tabanan\&ie=utf-8\&oe=utf-8\&client=firefox-bab. diakses pada tanggal 13 Mei 2017 Pukul 10:00 am. Giantourismbali: LAPORAN PENELITIAN LAPANGAN II PRODUK WISATA DI SEKITAR DESA WISATA PINGE KECAMATAN MARGA KABUPATEN TABANANhttp://giantourismbali.blogspot.co.id/2012/02 /laporan-penelitian-lapangan-ii-produk.html. diakses pada tanggal 09 Maret 2018 pukul 08:45 Pm 